\title{
Accumulation of organic and inorganic mercury from food in the tissues of Carcinus maenas: effect of waterborne selenium
}

\author{
Poul Bjerregaard, Lene Christensen \\ Ecotoxicology Group, Institute of Biology, Odense University, Campusvej 55, DK-5230 Odense M, Denmark
}

\begin{abstract}
Accumulation of organic and inorganic mercury from contaminated food into the tissues of selenium- and non-selenium-exposed shore crabs Carcinus maenas were investigated in the laboratory. Crabs fed homogenates of Cardium edule collected in the mercury-contaminated Nissum Bredning, Jutland, Denmark, assimilated 50 to $60 \%$ of ingested inorganic and organic mercury. Muscle and midgut gland contained approximately 50 to $60 \%$ and $40 \%$ respectively of both assimilated mercury species. Simultaneous exposure to selenite augmented accumulation of organic mercury in muscle and increased assimilation of organic mercury from the food. Accumulation of inorganic mercury was not affected by exposure to selenite. When the mercury concentration of the food was increased 10 -fold (by the addition of $\mathrm{HgCl}_{2}$ and $\mathrm{CH}_{3} \mathrm{HgCl}$ directly to the cockle homogenate), a higher percentage of the ingested inorganic mercury was assimilated by the crabs, $95 \%$ of the inorganic mercury being accumulated in the midgut gland. Percent assimilation and tissue distribution of organic mercury was less affected by increasing the concentration in the diet. The subcellular distribution of the 2 mercury species was almost identical. In the soluble fraction both mercury species were bound predominantly to proteins with a molecular weight (MW) of ca $12000 \mathrm{Da}$. In the soluble fraction, exposure to selenite diverted mercury from the 12000 Da region to high ( $M W>70000 \mathrm{Da}$ ) or very low (MW $<4000 \mathrm{Da}$ ) molecular weight proteins. Injected organic mercury was cleared from the haemolymph more rapidly than inorganic mercury, and clearance of both mercury species from the haemolymph proceeded faster in selenite-exposed crabs.
\end{abstract}

\section{INTRODUCTION}

Whereas organic mercury constitutes only a minor fraction $(0.5$ to $5 \%)$ of the total mercury $(0.01$ to $1.5 \mathrm{ng} \mathrm{Hg}^{-1}$ ) present in unpolluted seawater (Mason \& Fitzgerald 1990), marine organisms, especially those occupying higher trophic levels, generally accumulate organic mercury to higher levels than they do inorganic mercury (Knauer \& Martin 1972, Bernhard 1985). Several investigations show that shrimps (Fowler et al. 1978, Riisgård \& Fammé 1986) and fish (Pentreath 1976, Boudou \& Ribeyre 1985, Riisgård \& Hansen 1990) extract organic mercury from their food more efficiently than inorganic mercury, but the information on accumulation of mercury from food in benthic, carnivorous invertebrates is scarce.

Due to former discharges from the chemical factory 'Cheminova' in Jutland, Denmark, organisms inhabiting the western part of nearby Nissum Bredning have been exposed to elevated concentrations of mercury in their environment for decades (Kiorboe et al. 1983, Riisgård 1984). Cockles Cardium spp. in the most affected area contain up to $2 \mu \mathrm{g} \mathrm{Hg} \mathrm{g}^{-1}$ wet wt, of which 30 to $90 \%$ (depending on the age of the cockles) is organic mercury (Møhlenberg \& Riisgård 1988). Organic mercury in bivalves of this area is principally in the form of methylmercury, but phenylmercury has also been detected (Riisgard et al. 1985). Due to the chronic nature of the exposure, organisms from this area are considered very suitable for studies on transfer of mercury through the food chain.

Since the demonstration of the antagonistic effects of selenium on mercury toxicity in rat kidney (Parizek \& Ostadalova 1967), interactions between selenium and mercury have been studied intensively (see Magos \& Webb 1980 for review). In marine vertebrates, mercury and selenium concentrations often show marked positive correlations within specific tissues (Koeman et al. 
1973, 1975, Mackay et al. 1975, Norheim 1987), but the interactions between accumulation of mercury and selenium in organisms along marine food chains are poorly understood (see Pelletier 1985 for review).

Uptake and internal handling of trace metals other than mercury in the shore crab Carcinus maenas have been investigated in detail, and accumulation of cadmium in the tissues of $C$. maenas is influenced by exposure to selenium (Bjerregaard 1982, 1985a, 1988).

The present study was initiated to investigate mercury accumulation from contaminated food and subsequent subcellular binding of inorganic and organic mercury in the tissues of Carcinus maenas. Furthermore, the effects of selenium on these processes were assessed.

\section{MATERIALS AND METHODS}

Experimental animals. Cockles Cardium edule were collected from Nissum Bredning, Jutland, Denmark, at the locations most heavily contaminated with mercury (Kiørboe et al. 1983, Riisgård 1984). Shore crabs Carcinus maenas were caught in seine nets in Odense Fjord, Funen, Denmark, at salinities varying from 12 to $28 \%$. Odense Fjord is not contaminated with mercury.

Preparation of food. To obtain a homogeneous source of food, soft parts of several hundred Cardium edule were homogenised in a food-processor. Forty ml of commercial gelatin $\left(37^{\circ} \mathrm{C}\right)$ were added per $100 \mathrm{ml}$ homogenate and the mixture was cooled in a grid, yielding solid cubes of $1.55 \pm 0.11 \mathrm{~g}$ with $177 \pm 19 \mathrm{ng}$ inorganic mercury $g^{-1}$ wet $w t, 165 \pm 18 \mathrm{ng}$ organic mercury $g^{-1}$ wet $w t, 215 \pm 37 \mathrm{ng} \mathrm{Se}^{-1}$ wet wt and a solid content of $11.4 \pm 1.0 \%(\mathrm{n}=7)$. The food blocks were frozen prior to storage. They were thawed $1 \mathrm{~h}$ prior to feeding the crabs. The food blocks could be eaten by the crabs without significant loss of material to the seawater. For Expt 2, the cockle homogenate was enriched with mercury $\left(\mathrm{HgCl}_{2}\right.$ and $\mathrm{CH}_{3} \mathrm{HgCl}$ ) to give final concentrations of $2300 \mathrm{ng}$ inorganic mercury $\mathrm{g}^{-1}$ wet wt and $1900 \mathrm{ng}$ organic mercury $g^{-1}$ wet wt.

Experiment 1. Two groups of 20 male shore crabs (body wet wt $86 \pm 12 \mathrm{~g}$ ) were caught in September 1989. The crabs were held individually in 2.61 polystyrene aquaria. The water was aerated and no sediment was placed in the aquaria. After $10 \mathrm{~d}$ acclimation, $1 \mathrm{mg} \mathrm{Se}-\mathrm{SeO}_{3}^{2-} \mathrm{l}^{-1}$ was added to one of the groups. Every crab in both groups was fed 1 food block every $2 \mathrm{~d}$. The crabs ate all the food presented. Water was changed after each feeding session. Faecal pellets were collected for mercury analysis by means of a pipette from each aquarium every $2 \mathrm{~d}$. During the exposure period, temperature and salinity were $16.0 \pm$ $1.4{ }^{\circ} \mathrm{C}$ and $18.0 \pm 2.1 \%$.

After 10,20 and 30 d exposure, 5 or 6 crabs from each group were sacrificed. Gills, midgut gland, muscles, gonads and samples of haemolymph, hypodermis and carapace were taken out for mercury and selenium analysis. Five male crabs (body wet wt $84 \pm$ $14 \mathrm{~g})$ were analysed as a control group.

The subcellular distribution of selenium and inorganic and organic mercury in muscles and midgut gland of crabs exposed for $30 \mathrm{~d}$ was determined.

Experiment 2. Two groups of 5 female shore crabs (body wet wt $53 \pm 6 \mathrm{~g}$ ) were caught in March 1990 and transferred to two $10 \mathrm{l}$ polystyrene aquaria. After $10 \mathrm{~d}$ acclimation, $1 \mathrm{mg} \mathrm{Se}-\mathrm{SeO}_{3}{ }^{2-} \mathrm{l}^{-1}$ was added to one of the groups and each of the 10 crabs was fed 1 food block containing $2.11 \mu \mathrm{g}$ organic and $2.55 \mu \mathrm{g}$ inorganic mercury every $2 \mathrm{~d}$ for $30 \mathrm{~d}$. Prior to feeding, the crabs were placed individually in 2.6 l aquaria. Water in the exposure aquaria was changed every $2 \mathrm{~d}$. Temperature was $15.5 \pm 0.5^{\circ} \mathrm{C}$ and salinity was $15.3 \pm 3.5 \%$.

Concentrations of inorganic and organic mercury and selenium were determined in haemolymph, midgut gland, muscles, ovaries and gills. Subcellular distribution of selenium and inorganic and organic mercury in muscles and midgut gland were investigated.

Experiment 3. To investigate the turnover of mercury in the haemolymph of Carcinus maenas, 2 groups of male crabs (body wet wt $49 \pm 9 \mathrm{~g}$ ) caught in March 1990 were acclimated in the laboratory in 101 polystyrene aquaria for $11 \mathrm{~d}$ before $1 \mathrm{mg} \mathrm{Se}-\mathrm{SeO}_{3}{ }^{2-} \mathrm{l}^{-1}$ was added to 1 aquarium. After $21 \mathrm{~d}$ pre-exposure to selenite (only 1 group), $6.0 \mu \mathrm{g} \mathrm{Hg}-\mathrm{HgCl}_{2}$ and $6.0 \mu \mathrm{g}$ $\mathrm{Hg}-\mathrm{CH}_{3} \mathrm{HgCl}$ dissolved in $100 \mu \mathrm{l}$ crab ringer (Bjerregaard 1988) was injected into the haemolymph of each crab as described by Bjerregaard (1988). Haemolymph (ca $100 \mu \mathrm{l}$ ) was sampled through the arthrodial membranes of each of the crabs $0.5,1,2,4$, $8,26,50,97$ and $194 \mathrm{~h}$ after the injection, and concentrations of organic and inorganic mercury were determined. Salinity and temperature prior to exposure and during the experiment were $17 \pm 3 \%$ and $15.5 \pm 1.0^{\circ} \mathrm{C}$.

Experiment 4. Concentrations of organic mercury in muscles of 40 unexposed male crabs ranging in body size from 25 to $120 \mathrm{~g}$ wet wt were determined. The crabs were caught in September 1988.

Chemical analyses. Inorganic and organic mercury were determined according to Riisgård \& Hansen (1990) and selenium and total mercury (in carapace) were analysed as described by Sørensen \& Bjerregaard (1991). Tissue homogenisation and gel filtration procedures used in the determination of the subcellular distribution of mercury and selenium were described in Bjerregaard (1990) and Sørensen \& Bjerregaard (1991). 
Data treatment. One- and 2-way ANOVA tests were used to evaluate effects of exposure time and/or selenium treatment. Individual experimental groups were compared by Tukey's multiple comparisons test. Regression analysis was used to assess uptake rates. The statistical procedures were carried out with the PC program SYSTAT.

\section{RESULTS}

\section{Experiment 1}

Seven of the 40 crabs died during the exposure period.

In the control crabs inorganic mercury could be detected only in the hypodermis (Fig. 1j). Between 10 and $30 \mathrm{~d}$ of exposure to mercury-contaminated food, concentrations [ng ( $g$ dry $w t)^{-1}$ ] of inorganic mercury increased linearly with time in muscle $\left(\left[\mathrm{Hg}_{\text {inorg. }}\right]=\right.$ $6.7 d-1 ; r^{2}=0.71, p<0.0001 ;$ Fig. 1d) and midgut gland $\left(\left[\mathrm{Hg}_{\text {inorg. }}\right]=23 d+220 ; \mathrm{r}^{2}=0.39, \mathrm{p}<0.01\right.$; Fig. 1a). Between 10 and $30 \mathrm{~d}$ concentrations of inorganic mercury in gills and haemolymph fluctuated around $350 \mathrm{ng} \mathrm{Hg} \mathrm{g}^{-1}$ and $5 \mathrm{ng} \mathrm{Hg} \mathrm{ml}^{-1}$ respectively (Fig. 1g, o). Concentrations of inorganic mercury in the hypodermis ranged between 100 and $400 \mathrm{ng} \mathrm{Hg} \mathrm{g}^{-1}$ from 0 to $20 \mathrm{~d}_{\text {; }}$ on Day 30 concentrations of inorganic mercury had decreased below the detection limit (Fig. 1j). Inorganic mercury could be detected in only 1 gonad sample (Fig. 1i). Exposure to selenite did not consistently affect the accumulation of inorganic mercury

In the control crabs, organic mercury could only be detected in muscle (Fig. 1e). Between 10 and $30 \mathrm{~d}$ of exposure to mercury-contaminated food, concentrations of organic mercury increased linearly with time in muscle $\left(\left[\mathrm{Hg}_{\text {org }}\right]=9.1 d+229 ; \mathrm{r}^{2}=0.48, \mathrm{p}<0.01\right.$; Fig. 1e) and midgut gland $\left(\left[\mathrm{Hg}_{\text {org }}\right]=10 d+343 ; \mathrm{r}^{2}=\right.$ $0.26, p<0.05$; Fig. 1b). No consistent accumulation of organic mercury was found in the remaining tissues (Fig. 1h, k, m, p). Exposure to selenite decreased and increased accumulation of organic mercury in midgut gland $(p=0.001)$ and muscle $(p<0.001)$ respectively (Fig 1b, e); the regression line for organic mercury in muscle of the selenite-exposed group is: $\left(\left[\mathrm{Hg}_{\text {org. }}\right]=\right.$ $\left.19 d+207 ; \mathrm{r}^{2}=0.75, \mathrm{p}<0.0001\right)$.

Mercury could not be detected in the carapace.

The faecal pellets collected during the experiment constituted $1.5 \pm 0.6 \%$ of the food ingested (dry wt); there was no difference between the 2 groups (Table 1).

Concentrations of mercury in the faecal pellets collected during the experiments are shown in Table 1. No trend of changes in the concentrations of either of
Table 1. Carcinus maenas. Concentrations of inorganic and organic mercury in faecal pellets collected from crabs fed a diet containing $1554 \pm 34 \mathrm{ng}$ inorganic $\mathrm{Hg} \mathrm{g}^{-1}$ dry wt and $1453 \pm 35 \mathrm{ng}$ organic $\mathrm{Hg} \mathrm{g}^{-1}$ dry wt (Expt 1). CF: concentration factor $[\mathrm{Hg}]_{\text {faecrs: }}[\mathrm{Hg}]_{\text {rood. }}$ Mean $\pm \mathrm{SD}$ for $17(-\mathrm{Se})$ and $16(+\mathrm{Se})$ crabs are given. Multiple determinations of mercury concentrations were carried out for each crab

\begin{tabular}{|c|c|c|}
\hline & - Selenite & + Selenite \\
\hline \multicolumn{3}{|l|}{ Faeces collected } \\
\hline (\% of ingested) & $1.4 \pm 0.7$ & $1.6 \pm 0.6$ \\
\hline \multicolumn{3}{|l|}{$\mu \mathrm{g} \mathrm{Hg} \mathrm{g}{ }^{-1}$ dry wt } \\
\hline Inorganic $\mathrm{Hg}$ & $8.7 \pm 2.9$ & $6.5 \pm 1.7^{\bullet}$ \\
\hline Organic $\mathrm{Hg}$ & $1.0 \pm 0.5$ & $3.4 \pm 2.3 \cdots$ \\
\hline \multicolumn{3}{|c|}{$\%$ of ingested $\mathrm{Hg}$ collected in faeces } \\
\hline Inorganic $\mathrm{Hg}$ & $7.6 \pm 4.3$ & $6.4 \pm 2.5$ \\
\hline Organic $\mathrm{Hg}$ & $1.0 \pm 0.7$ & $4.2 \pm 4.1 \cdots$ \\
\hline \multicolumn{3}{|l|}{$\mathrm{CF}$ for $\mathrm{Hg}$ in faeces } \\
\hline Inorganic $\mathrm{Hg}$ & $5.6 \pm 1.9$ & $4.2 \pm 1.1^{\bullet}$ \\
\hline Organic $\mathrm{Hg}$ & $0.7 \pm 0.4$ & $2.3 \pm 1.6 \cdots$ \\
\hline \multicolumn{3}{|c|}{${ }^{\circ} p<0.05 ; \cdots p<0.01 ; \cdots p<0.001$} \\
\hline
\end{tabular}

the mercury species was observed during the exposure period. Concentrations of inorganic mercury exceeded those of organic mercury in both groups ( $p<0.0001)$. The concentration of organic mercury in faeces was elevated in the selenite-exposed group, whereas concentrations of inorganic mercury were slightly lowered (Table 1). In the group not exposed to selenite, concentrations of organic and inorganic mercury in the faecal pellets of individual crabs were correlated $(\mathrm{r}=0.65$, $p<0.01)$; no such correlation was present in the selenite-exposed group ( $\mathrm{r}=0.12, \mathrm{p}=0.7$ ).

Approximately half of the mercury ingested by the crabs exposed to mercury in their food was retained in the tissues investigated (Fig. 2). The retention efficiency for inorganic mercury (which was not affected by selenite) decreased significantly ( $p<0.01)$ from Day 10 to Days $20 \& 30$ (Fig. 2a). Retention efficiency for organic mercury increased $(\mathrm{p}<0.001)$ in the selenite-exposed group (Fig. 2b)

Muscle and midgut gland accounted for $>90 \%$ of the mercury accumulated during the experiment (Fig. 3a, c). Simultaneous exposure to selenite altered the relative amounts of organic mercury accumulated in these tissues (Fig. 3d), whereas the distribution of inorganic mercury was not affected (Fig. 3 b).

In the group exposed to selenite in the water, selenium accumulated linearly with time in midgut gland $\left([\mathrm{Se}]_{\mu g g^{-1}}\right.$ dry wt $=0.25 d+5.7 ; \mathrm{r}^{2}=0.83, \mathrm{p}<0.0001$; Fig. 1c), muscle $\left([\mathrm{Se}]_{\mu \mathrm{g} \mathrm{g}}{ }^{-1} \mathrm{~d}\right.$ sy wt $=0.10 d+3.0 ; \mathrm{r}^{2}=0.65$, $\mathrm{p}<0.0001$; Fig. 1f) and haemolymph ([Se $]_{\mu \mathrm{g} \mathrm{ml}}-1 \mathrm{dry} w \mathrm{t}=$ $0.0077 d+0.36 ; \mathrm{r}^{2}=0.62, \mathrm{p}<0.0001 ;$ Fig. 1q). Gills 

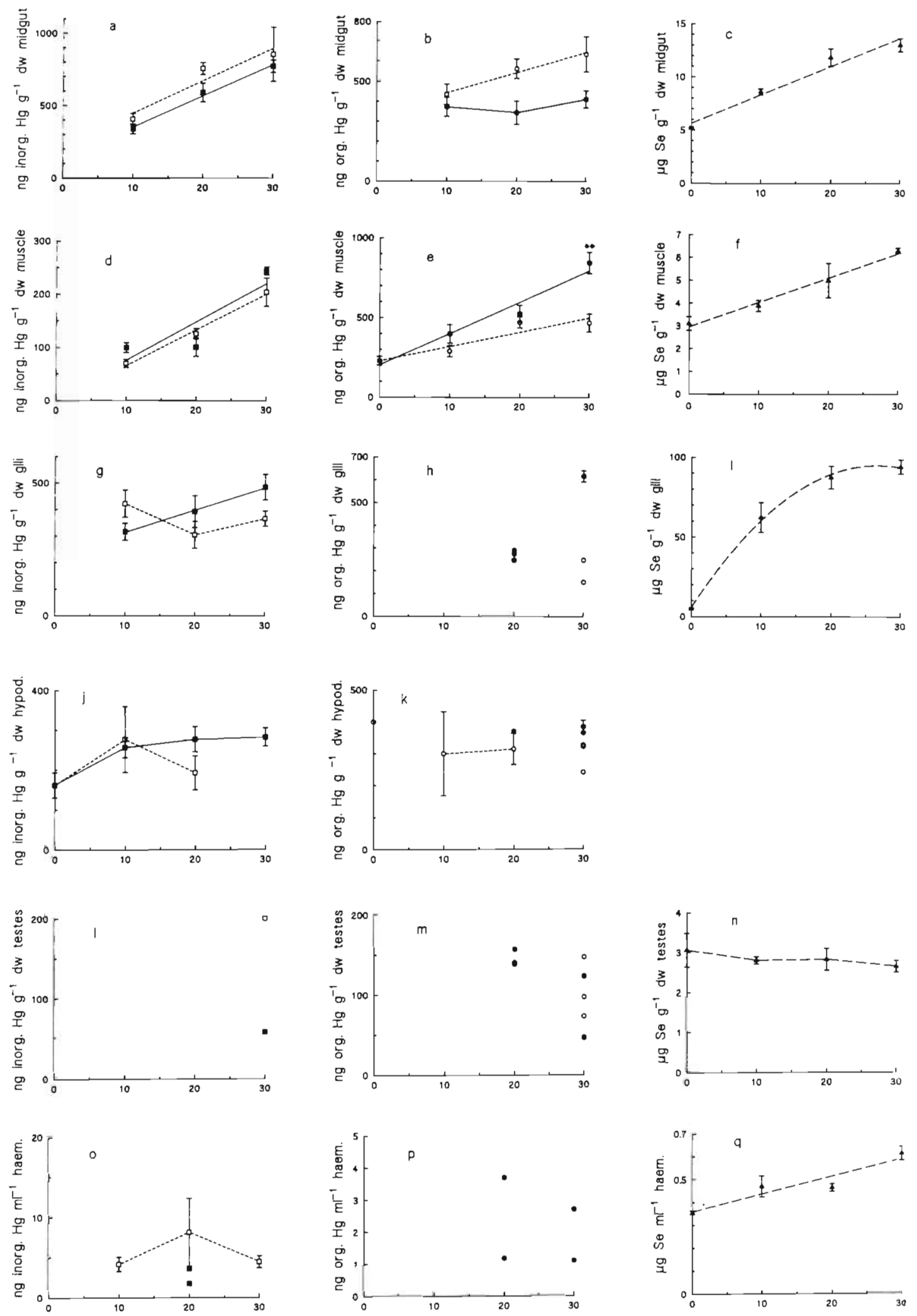

Exposure time (days) 
accumulated selenium at $5.5 \mu \mathrm{g} \mathrm{Se} \mathrm{g}^{-1} \mathrm{~d}^{-1}$ over the initial $10 \mathrm{~d}$; thereafter the accumulation rate decreased and ca $100 \mu \mathrm{g} \mathrm{Se}^{-1}$ gill dry wt was reached after $30 \mathrm{~d}$ (Fig. 1i). Selenium accumulation in the gills could be described by the equation: $[\mathrm{Se}]_{\mu \mathrm{g} \mathrm{g}}{ }^{-1} \mathrm{dry}$ wt $=5.7+6.7 d-$ $0.12 d^{2} ; r^{2}=0.88, p<0.0001$ ).

Selenium concentrations in the gonads were not altered during the exposure period (Fig. 1n).

Organic mercury was bound almost exclusively in the crude nuclear/cell debris fraction of the muscles, whereas a higher fraction was bound in the soluble fraction of the midgut gland (Table 2). In the midgut gland inorganic mercury appeared especially in the microsomal and soluble fractions. In muscle, concentrations of inorganic mercury were too low for proper recovery (Table 2). Differences between the seleniteexposed and the non-selenite-exposed group seemed to be related to differences in homogenisation efficiency (Table 2). Selenium appeared especially in microsomal and soluble fractions of the midgut gland and differences in selenium distribution between the 2 groups were probably also accounted for by different homogenisation efficiencies (Table 2). In muscle, selenium was distributed according to the amount of dry matter in the subcellular fractions (Table 2); more than $95 \%$ of the selenium in both groups was found in crude nuclear/cell debris and soluble fractions (Table 2).

\section{Experiment 2}

One crab died in the selenite-exposed group. Concentrations of inorganic and organic mercury and selenium in the tissues of crabs fed $2.55 \mu \mathrm{g}$ inorganic mercury and $2.11 \mu \mathrm{g}$ organic mercury every $2 \mathrm{~d}$ for $30 \mathrm{~d}$ are shown in Table 3 . Inorganic mercury was detected in all tissues but accumulated predominantly in the midgut gland. Organic mercury was more evenly distributed among the organs with the highest amount being accumulated in muscles (Fig. 3). Concurrent exposure to selenite in the water reduced accumulation of both inorganic and organic mercury in the midgut gland and increased accumulation of organic mercury in muscles and gills (Table 3 ).

In the midgut gland, organic mercury was evenly distributed among crude, microsomal and soluble fractions, whereas the mitochondrial fraction contained a
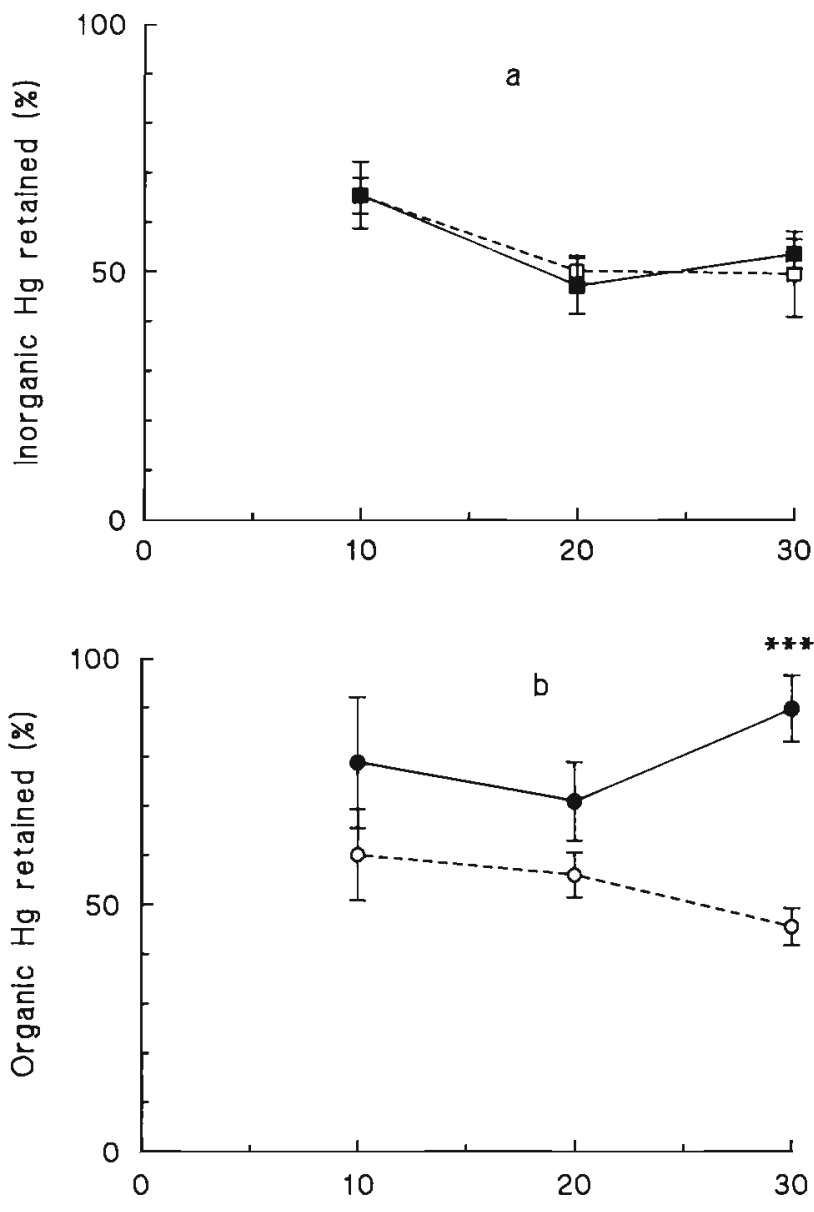

Exposure time (days)

Fig. 2. Carcinus maenas. Retention (\%) of total amount of (a) inorganic and (b) organic mercury ingested by the crabs fed homogenised cockles containing $274 \mathrm{ng}$ inorganic and 256 organic mercury every $2 \mathrm{~d}$ for $30 \mathrm{~d}$. Open symbols and broken lines: crabs exposed only to mercury in food; filled symbols and solid lines: crabs exposed to mercury in food and to $1 \mathrm{mg} \mathrm{Se}-\mathrm{SeO}_{3}{ }^{2-} 1^{-1}, \cdots p<0.001$ (Tukey's test)

smaller amount of organic mercury (Table 2). Inorganic mercury was bound in the midgut gland in the order microsomal $>$ crude $>$ soluble $>$ mitochondrial fraction (Table 2). In muscle, inorganic and organic mercury showed almost identical subcellular distribution with ca two-thirds and one-third in crude and

Fig. 1. Carcinus maenas. Accumulation of inorganic mercury (left column) and organic mercury (centre column) in the tissues of crabs fed homogenised cockles containing $274 \mathrm{ng}$ inorganic mercury and $256 \mathrm{ng}$ organic mercury every 2 d. Open symbols and broken lines: crabs exposed only to mercury in food; filled symbols and solid lines: crabs simultaneously exposed to $1 \mathrm{mg} \mathrm{Se}-\mathrm{SeO}_{3}{ }^{2-} 1^{-1}$ The right column shows accumulation of selenium in the tissues of selenite-exposed crabs. Regression equations are given in the text. Mean $\pm \mathrm{SE}$ for 5 or 6 crabs is given if all values were above the detection limit; otherwise individual values are shown. The detection limit varied between 50 and $100 \mathrm{ng} \mathrm{Hg} \mathrm{g}^{-1}$, depending on the amount of tissue available. $\cdots p<0.01$ (Tukey's test) 

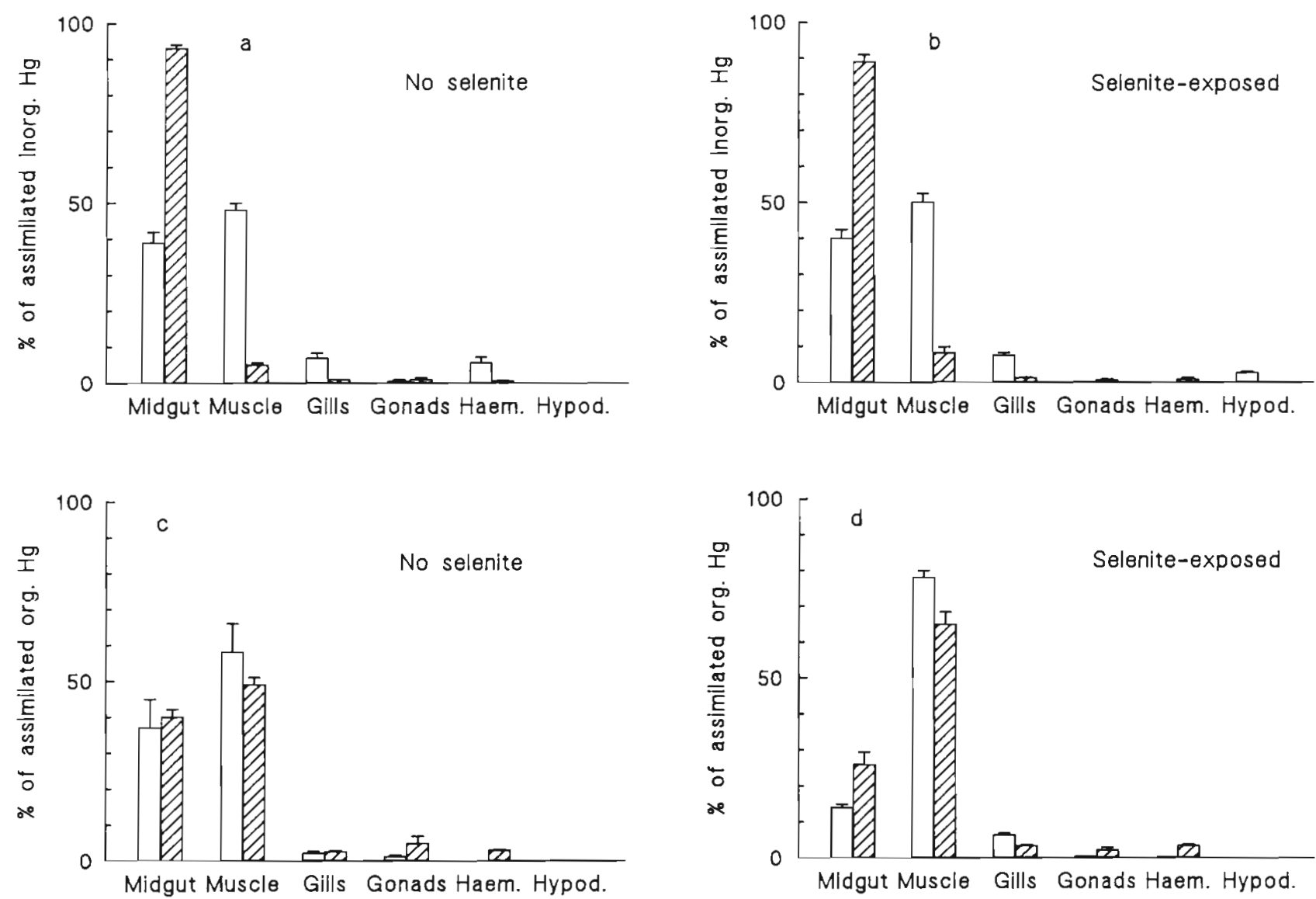

Fig. 3. Carcinus maenas. Distribution among organs of mercury assimilated from food during Expt $1(\square)$ and Expt 2 ( $(2)$

soluble fractions respectively and very little in mitochondrial and microsomal fractions (Table 2). Exposure to selenite had no consistent effect on the subcellular distribution of either of the 2 mercury species (Table 2).

In the soluble fraction of the midgut gland both organic and inorganic mercury were bound in high molecular wt proteins (MW $>70000 \mathrm{Da})$ and proteins with a molecular weight of Ca 12000 Da (Fig. 4a). Exposure to selenite removed most of the mercury from the $12000 \mathrm{Da}$ peak (Fig. 4b). Inorganic mercury was moved to the high molecular weight fraction and organic mercury was also moved to a fraction with a molecular weight $<4000$ Da (Fig. 4b). Selenium was bound predominantly in the high molecular weight fraction and in a peak of molecular weight $<4000$ Da (Fig. 4c).

\section{Experiment 3}

All of the crabs survived the pre-exposure period, but substantial mortality was registered in the days following the mercury injection (Fig. 5). Organic mercury was eliminated from the haemolymph much faster than inorganic mercury. Thirty minutes after the injection of equal amounts of inorganic and organic mercury, the haemolymph contained ca $650 \mathrm{ng}$ inorganic and ca $300 \mathrm{ng}$ organic mercury $\mathrm{ml}^{-1}$, indicating that more than half of the organic mercury had been eliminated from the haemolymph before the first sample was taken (Fig. 5). Both inorganic and organic mercury were eliminated faster in crabs pre-exposed to selenite than in the group not exposed to selenite (Fig. 5).

\section{Experiment 4}

Concentrations of organic mercury in muscles of 40 unexposed crabs in the size range 25 to $120 \mathrm{~g}$ wet wt were $227 \pm 70 \mathrm{ng} \mathrm{Hg} \mathrm{g}^{-1}$ dry wt. Size of the crabs and concentrations of organic mercury in the muscles were not correlated $\left(\mathrm{r}^{2}=0.05, \mathrm{p}=\right.$ $0.15)$ 
Table 2. Carcinus maenas. Distribution of organic and inorganic mercury and selenium in crude nuclear/cell debris (Crude), mitochondrial (Mitoc.), microsomal (Micros.) and soluble fractions in midgut gland and muscle of crabs exposed to organic

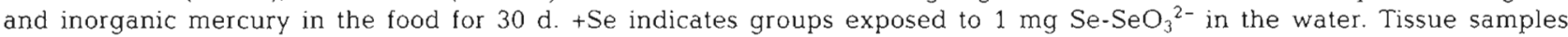
were pooled from $5(-\mathrm{Se})$ and $6(+\mathrm{Se})$ in Expt 1 and $5(-\mathrm{Se})$ and $4(+\mathrm{Se})$ animals in Expt 2 . Percentages of the total amount of

$\mathrm{Hg}$ and Se recovered are given. Recoveries given in \%. nd: below detection limit

\begin{tabular}{|c|c|c|c|c|c|c|c|c|c|c|c|}
\hline & & & & xperimen & 1 & & & & periment & & \\
\hline & & & Fra & tion & & Recovery & & Frac & tion & & Recovery \\
\hline & & Crude & Mitoch. & Micros. & Soluble & & Crude & Mitoch. & Micros. & Soluble & \\
\hline Mercury & & & & & & & & & & & \\
\hline Midgut gland & & & & & & & & & & & \\
\hline$\%$ of dry $w t$ & $-\mathrm{Se}$ & 30.5 & 4.7 & 12.9 & 51.9 & & 21.3 & 2.8 & 11.9 & 64.0 & \\
\hline & $+\mathrm{Se}$ & 41.6 & 1.5 & 5.5 & 48.6 & & 25.4 & 3.1 & 7.4 & 64.1 & \\
\hline Organic $\mathrm{Hg}$ & $-\mathrm{Se}$ & 10.8 & 10.0 & 40.6 & 38.6 & 131 & 21.9 & 9.4 & 41.5 & 27.1 & 71 \\
\hline & $+\mathrm{Se}$ & 9.1 & 5.5 & 17.4 & 68.1 & 108 & 29.3 & 9.4 & 27.6 & 33.7 & 75 \\
\hline Inorganic $\mathrm{Hg}$ & $-\mathrm{Se}$ & 17.8 & 9.2 & 35.3 & 37.7 & 90 & 29.6 & 7.6 & 46.9 & 15.8 & 55 \\
\hline & $+\mathrm{Se}$ & 19.9 & 5.1 & 19.7 & 55.3 & 80 & 39.2 & 8.5 & 36.2 & 16.4 & 70 \\
\hline Muscle & & & & & & & & & & & \\
\hline$\%$ of dry $w t$ & $-\mathrm{Se}$ & 60.1 & 0.5 & 2.7 & 36.7 & & 64.9 & 0.5 & 2.6 & 32.0 & \\
\hline & $+\mathrm{Se}$ & 64.0 & 0.8 & 2.8 & 32.4 & & 64.7 & 0.4 & 3.3 & 31.6 & \\
\hline Organic Hg & $-\mathrm{Se}$ & 97.4 & nd & 2.6 & nd & 79 & 65.1 & 1.0 & 2.9 & 30.9 & 72 \\
\hline & $+\mathrm{Se}$ & 93.8 & 1.4 & 3.5 & 1.3 & 67 & 66.2 & 0.7 & 4.3 & 28.9 & 91 \\
\hline Inorganic $\mathrm{Hg}$ & $-\mathrm{Se}$ & 100 & nd & nd & nd & 31 & 72.0 & 1.8 & 2.5 & 23.7 & 115 \\
\hline & $+\mathrm{Se}$ & 57.5 & nd & 42.5 & nd & 29 & 60.6 & 2.0 & 5.3 & 32.1 & 82 \\
\hline Selenium & & & & & & & & & & & \\
\hline Midgut gland & & & & & & & & & & & \\
\hline$\%$ of dry wt & $-\mathrm{Se}$ & 32.2 & 3.4 & 13.7 & 50.7 & & 20.4 & 3.2 & 9.4 & 67.0 & \\
\hline & $+\mathrm{Se}$ & 41.9 & 1.5 & 7.2 & 49.4 & & 23.6 & 3.4 & 8.6 & 64.4 & \\
\hline Selenium & $-\mathrm{Se}$ & 16.6 & 8.1 & 25.5 & 49.9 & 79 & 19.2 & 7.1 & 21.2 & 52.4 & 97 \\
\hline & $+\mathrm{Se}$ & 18.9 & 5.4 & 17.9 & 57.8 & 92 & 25.1 & 8.6 & 29.7 & 36.7 & 94 \\
\hline Muscle & & & & & & & & & & & \\
\hline$\%$ of dry wt & $-\mathrm{Se}$ & 52.2 & 0.4 & 2.5 & 44.9 & & 65.6 & 0.4 & 2.5 & 31.5 & \\
\hline & $+\mathrm{Se}$ & 54.8 & 0.3 & 2.4 & 42.5 & & 66.0 & 0.5 & 2.4 & 31.1 & \\
\hline Selenium & $-\mathrm{Se}$ & 56.6 & 0.8 & 3.5 & 39.1 & 64 & 73.1 & 1.0 & 2.7 & 23.2 & 119 \\
\hline & $+\mathrm{Se}$ & 58.6 & 0.7 & 3.3 & 37.5 & 64 & 70.0 & 0.9 & 2.7 & 26.4 & 95 \\
\hline
\end{tabular}

Table 3. Carcinus maenas. Concentrations of mercury and selenium in the tissues of crabs fed $2.11 \mu \mathrm{g}$ organic and $2.55 \mu \mathrm{g}$ inorganic mercury every $2 \mathrm{~d}$ for $30 \mathrm{~d}$. + Se: group exposed to $1 \mathrm{mg} \mathrm{Se}-\mathrm{SeO}_{3}{ }^{2-}$ in the water. Mean $\pm \mathrm{SD}$ for 5 ( $-\mathrm{Se}$ ) and 4 (+Se) crabs are given. $\cdot \mathrm{p}<0.05 ; \cdots \mathrm{p}<0.01 ; \cdots \mathrm{p}<0.001$. Tissue concentrations based on dry weight; haemolymph values given as ng Hg or Se $\mathrm{ml}^{-1}$

\begin{tabular}{|c|c|c|c|c|c|c|}
\hline & \multicolumn{2}{|c|}{$\mu g$ organic $\mathrm{Hg} \mathrm{g}^{-1}$} & \multicolumn{2}{|c|}{$\mu \mathrm{g}$ inorganic $\mathrm{Hg} \mathrm{g}^{-1}$} & \multicolumn{2}{|c|}{$\mu \mathrm{gSe} \mathrm{g}^{-1}$} \\
\hline & $-\mathrm{Se}$ & $+\mathrm{Se}$ & $-\mathrm{Se}$ & $+\mathrm{Se}$ & $-\mathrm{Se}$ & $+\mathrm{Se}$ \\
\hline Midgut gland & $9.7 \pm 1.1$ & $6.0 \pm 1.1 \cdots$ & $47 \pm 6$ & $30 \pm 4 \cdots$ & $3.7 \pm 1.0$ & $9.6 \pm 1.2 \cdots$ \\
\hline Muscle & $3.4 \pm 0.5$ & $4.9 \pm 0.7 \cdots$ & $0.7 \pm 0.2$ & $0.9 \pm 0.4$ & $2.2 \pm 0.4$ & $5.1 \pm 0.5 \cdots$ \\
\hline Gills & $1.9 \pm 0.5$ & $3.0 \pm 0.6^{\bullet}$ & $1.4 \pm 0.5$ & $1.5 \pm 0.4$ & $3.9 \pm 0.6$ & $170 \pm 97^{\circ}$ \\
\hline Ovaries & $3.1 \pm 0.3$ & $2.4 \pm 1.2$ & $0.6 \pm 0.2$ & $1.0 \pm 0.6$ & $4.8 \pm 0.6$ & $14 \pm 2 \cdots$ \\
\hline Haemolymph & $43 \pm 5$ & $48 \pm 9$ & $16 \pm 10$ & a & $0.13 \pm 0.03$ & $0.23 \pm 0.05^{\circ}$ \\
\hline Hg retained (\%) & $59 \pm 7$ & $62 \pm 9$ & $102 \pm 15$ & $74 \pm 11$ & & \\
\hline
\end{tabular}



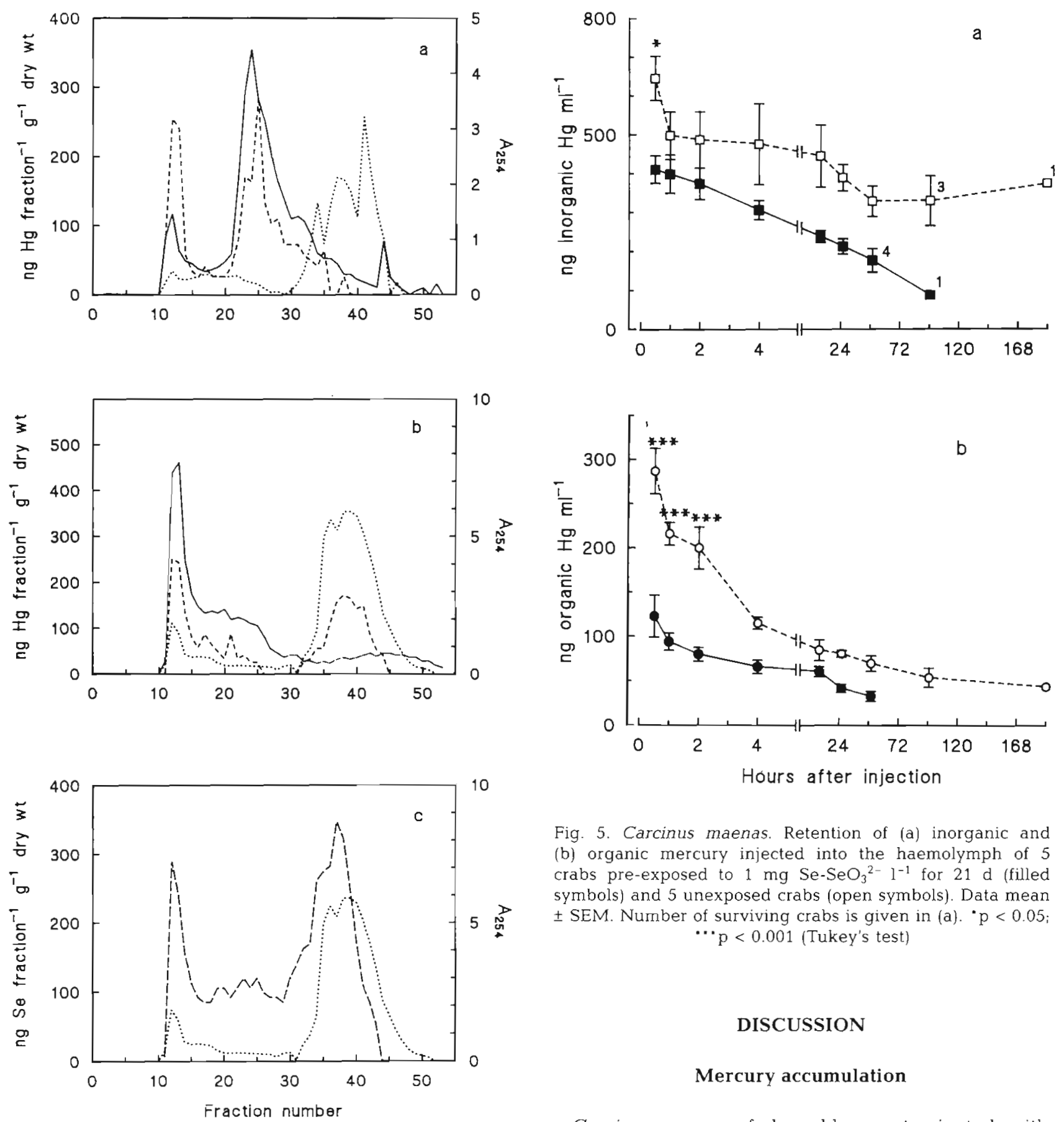

Fig. 5. Carcinus maenas. Retention of (a) inorganic and (b) organic mercury injected into the haemolymph of 5 crabs pre-exposed to $1 \mathrm{mg} \mathrm{Se}-\mathrm{SeO}_{3}{ }^{2-} \mathrm{l}^{-1}$ for $21 \mathrm{~d}$ (filled symbols) and 5 unexposed crabs (open symbols). Data mean \pm SEM. Number of surviving crabs is given in (a). $" p<0.05$;

$\cdots p<0.001$ (Tukey's test)

\section{DISCUSSION}

\section{Mercury accumulation}

Carcinus maenas fed cockles contaminated with

Fig. 4. Carcinus maenas. Sephadex G-75 elution profiles for the soluble fraction of hepatopancreas from crabs fed $2.11 \mu \mathrm{g}$ organic and $2.55 \mu \mathrm{g}$ inorganic mercury every $2 \mathrm{~d}$ for $30 \mathrm{~d}$ (Expt 2). ( $\longrightarrow$ ) inorganic mercury, (-- ) organic mercury; $(\cdots \cdots)$ : absorbance at $254 \mathrm{~nm}(---)$ in (c): selenium. (a) Pooled from 5 crabs exposed only to mercury in food (b) Pooled from 4 crabs exposed to mercury in food and to $1 \mathrm{mg}$ $\mathrm{Se}-\mathrm{SeO}_{3}{ }^{2-} \mathrm{l}^{-1}$ (c) Distribution of selenium in the seleniteexposed group. The calibration proteins albumin (45000 Dal, chymotrypsinogen A (25000 Da) and cytochrome c(12500 Da) eluted in peaks at Fractions 15, $20 \& 25$ respectively

mercury in nature assimilated between 40 and $60 \%$ of both organic and inorganic mercury ingested. Shrimps Crangon crangon fed mussels from the same mercurycontaminated area as the crabs in the present study retained about $4 \%$ of the inorganic and $75 \%$ of the organic mercury during a 4 wk period (Riisgard \& Fammé 1986), and shrimps Lysmata seticaudata assimilated more methylmercury than inorganic mercury from food (Fowler et al. 1978). Reasons for this difference between the 2 species of shrimps and 
C. maenas is not obvious, but assimilation efficiencies for organic mercury in fish also show large variation between different species (Phillips \& Gregory 1979).

Both mercury species are accumulated predominantly in midgut gland and muscles of Carcinus maenas. Neither of the 2 tissues reach steady mercury concentrations during 1 mo feeding, but after the exposure period 45 and $69 \%$ of the total mercury content in midgut gland and muscle respectively is organic mercury. Comparable mercury distribution was reported for blue crabs Callinectes sapidus collected in a mercurycontaminated salt marsh in the USA [57 and 33\% organic mercury in muscle and midgut gland respectively (Gardner et al. 1978)]. In the crab Mursia gaudichaudii collected off California, USA, 87 and $16 \%$ of the total mercury in muscle and midgut gland respectively was organic mercury (Eganhouse \& Young 1978); similar results were found for muscles of unexposed $C$. maenas where only organic mercury could be detected. Likewise, the portunid crab Thalamita crenata concentrated ${ }^{203} \mathrm{Hg}$ from food predominantly in viscera, while the highest background mercury concentrations were found in muscles (Luoma 1976). Whereas many aquatic organisms keep on accumulating organic mercury during their entire life span (Johnels et al. 1967, Bache et al. 1971, Bernhard 1985), the present results for unexposed crabs give no evidence that larger crabs contain more organic mercury than smaller ones. On the contrary, the fact that the apparent assimilation efficiency for both mercury species shows a tendency to decrease during the experimental period may suggest that some of the mercury taken up initially is eliminated from the organism. In many aquatic organisms, accumulated organic mercury is eliminated very slowly (Pentreath 1976) or hardly at all (Riisgård et al. 1985). Thus, further studies are required to see if $C$. maenas can eliminate organic mercury efficiently enough to match uptake.

Whereas organic mercury was similarly distributed among the organs in the 2 experiments, inorganic mercury was accumulated almost exclusively in the midgut gland after mercury had been added to the cockle homogenate to elevate the mercury dose in the diet (Fig. 3). The first experiment was carried out with male crabs in September and the second with female crabs in April. Sexual differences in metal handling have not been reported for crustaceans, but uptake (Bjerregaard 1985b) and effects (Bjerregaard \& Vislie 1985) of waterborne heavy metals in Carcinus maenas vary with season and/or moult cycle. The extra inorganic mercury added to the cockle homogenate may also be bound differently from the inorganic mercury accumulated in the cockles in situ, and this may also affect the way in which the metal is absorbed from the food and handled internally in the crab. Perhaps the higher dose given in the second experiment surpasses the binding capacity for inorganic mercury in the muscles, resulting in more inorganic mercury being available for accumulation in the midgut gland.

Organic mercury transferred to the haemolymph is rapidly taken up by the tissues. The turnover of inorganic mercury in the haemolymph is somewhat slower with a half-life comparable to that of cadmium (Bjerregaard 1988, 1990).

The subcellular distribution of the 2 mercury species appears to be almost identical. In muscle, mercury is bound almost exclusively in the crude cell/nuclear and the soluble fraction, whereas the microsomal fraction contains an appreciable amount of the mercury in the midgut gland. Most of the soluble mercury in the midgut gland is bound in proteins with a molecular weight of approximately $12000 \mathrm{Da}$. Wong \& Rainbow (1986a, b) identified 2 metal-binding proteins in the midgut gland of Carcinus maenas with molecular weights of 4100 and $10100 \mathrm{Da}$. The Sephadex G-50 separation used by Wong \& Rainbow $(1986 a$, b) should give a more reliable molecular weight determination in the low range than the Sephadex G-75 separation, and the protein to which mercury binds in the present study is probably identical to Wong \& Rainbow's $(1986 \mathrm{a}$, b) 10100 protein. In C. maenas, production of this protein is - with a large variability between individual crabs - induced by exposure to cadmium, copper and zinc (Wong \& Rainbow $1986 \mathrm{~b})$, but the inducing effect of mercury has not been investigated in C. maenas. In the crab Scylla serrata, exposure to mercury did not induce production of metallothionein, although exposure to cadmium and zinc did (Olafson et al. 1979)

\section{Selenium accumulation}

Selenium is accumulated in gills, midgut gland, muscles and haemolymph but not in gonads of crabs exposed to $1 \mathrm{mg} \mathrm{Se}-\mathrm{SeO}_{3}{ }^{2-} \mathrm{l}^{-1}$. Accumulation rates over $30 \mathrm{~d}$ for male (Expt 1) and female (Expt 2) crabs were identical. Accumulation rates for selenium in the internal tissues (midgut gland and muscles) are much higher in the present experiments than in experiments where starved crabs were exposed to an identical selenite concentration plus $1 \mathrm{mg} \mathrm{Cd} \mathrm{l^{-1 }}$ (Bjerregaard 1982). The indication that exposure to cadmium augments elimination of selenium from muscle and midgut gland of Carcinus maenas (Bjerregaard 1982) is further supported by the higher selenium uptake rates observed in the present study. The possibility that feeding during experiments may augment accumulation of selenium from water should, however, be taken into consideration. Overall, there is a general paucity of knowledge concerning internal handling and metabolism of selenium in crustaceans. 


\section{Effect of selenium on mercury accumulation}

Accumulation of organic mercury from in situ contaminated cockles is augmented in muscles and reduced in midgut gland of Carcinus maenas simultaneously exposed to selenite. These results are consistent in the 2 experiments. In the experiment with the highest mercury content in the diet, selenite further augmented accumulation of organic mercury in the gills and reduced accumulation of inorganic mercury in the midgut gland

There is very little information on the interaction between selenium and mercury in crustaceans. In the shrimp Palaemon elegans, injected inorganic mercury is retained more efficiently in animals preinjected with selenium (Lucu \& Skreblin 1981). This does not seem to be the case in Carcinus maenas where selenium does not augment the general assimilation efficiency for inorganic mercury given in the food. In marine invertebrates, interactions between accumulation of the 2 elements have been found in mussels (Pelletier 1986, Davies \& Russel 1988), clams (Patel et al. 1988) and sea stars (Sørensen \& Bjerregaard 1991), the patterns of interactions, however, being different. Genuine differences between various taxa and species probably exist, but element concentrations, administration route (food/water/injection) and mode of investigation (whole body/individual tissues) may also influence the results.

Exposure to selenite strongly augments accumulation of cadmium from seawater in gills and haemolymph of Carcinus maenas (Bjerregaard 1982, 1985a) and the turnover of cadmium in the haemolymph is much slower in selenite-exposed crabs (Bjerregaard 1988). As far as turnover in the haemolymph is concerned, both species of mercury are affected in quite the opposite way by exposure to selenium. Both mercury and cadmium bind to haemocyanin (Brouwer \& Engel 1982), but the different way in which selenium affects the half-life of the 2 elements in the haemolymph of C. maenas may suggest different binding sites or properties on haemocyanin for the 2 metals.

Selenite-exposed crabs assimilate a higher percentage of the organic mercury ingested and simultaneously lose a higher fraction in their faeces. In the nonselenite-exposed crabs, concentrations of inorganic and organic mercury in the faeces of individual crabs are positively correlated, possibly reflecting a common dependency on physiological processes (e.g. gut passage time). This correlation is not found in the seleniteexposed group and the chemical form of the mercury lost via the faeces in this group should be investigated.

Although exposure to selenium affects the accumulation of 1 or both mercury species in muscle and midgut gland, the distribution of mercury between the
3 insoluble and the soluble fractions of the tissue does not change. In the soluble fraction, however, both species of mercury are diverted from metallothionein into high (inorganic mercury) and low and high (organic mercury) molecular weight proteins. Inorganic mercury has a higher affinity for vertebrate metallothionein than organic mercury (Chen et al. 1973). Exposure to selenite may affect distribution of both mercury species in soluble as well as insoluble fractions of vertebrate tissues, but the exact nature of the interaction varies with animal species, tissue and dose of mercury and/or selenium (for review see Magos \& Webb 1980). However, treating rats with selenium prevented binding of methylmercury to a $10000 \mathrm{Da}$ protein in the kidneys (Chen et a1. 1975). This resembles the effect of selenium on the binding of organic mercury in the soluble fraction of the midgut gland of Carcinus maenas. On the other hand selenium does not affect the binding of inorganic mercury to $10000 \mathrm{Da}$ proteins in rat liver (Fang 1977). Generally, the biochemical basis for interaction between selenium and mercury needs further elucidation.

Acknowledgements. We thank Dr scient. H. U. Riisgård for advice on the mercury analysis and Prof. M. H. Depledge for critical comments on the manuscript. The project was supported by grants from the Danish Natural Science Council.

\section{LITERATURE CITED}

Bache, C. A., Gutenmann, W. H., Lisk, D. J. (1971). Residues of total mercury and methylmercuric salts in lake trout as a function of age. Science 172: 951-952

Bernhard, M. (1985). Mercury accumulation in a pelagic food chain. In: Martell, A. E., Irgolic, K. (eds.) US-Italian workshop on environmental inorganic chemistry. Chemie Verlag, Weinheim, p. 349-358

Bjerregaard, P. (1982). Accumulation of cadmium and selenium and their mutual interaction in the shore crab Carcinus maenas (L.). Aquat. Toxicol. 2: 113-125

Bjerregaard, P. (1985a). Effect of selenium on cadmium uptake in the shore crab Carcinus maenas (L.). Aquat. Toxicol. 7: 177-189

Bjerregaard, P. (1985b). Optagelse og effekter af tungmetaller marine organismer og økosystemer. Ph.D. thesis, Odense University, Odense

Bjerregaard, P. (1988). Interaction between selenium and cadmium in the hemolymph of the shore crab Carcinus maenas (L.). Aquat. Toxicol. 13: 1-12

Bjerregaard, P. (1990). Influence of physiological condition on cadmium transport from haemolymph to hepatopancreas in Carcinus maenas. Mar. Biol. 106: 199-209

Bjerregaard, P., Vislie, T. (1985). Effects of mercury on ion and osmoregulation in the shore crab Carcinus maenas. Comp Biochem. Physiol. 82C: 227-230

Boudou, A., Ribeyre, F. (1985). Experimental study of trophic contamination of Salmo gairdneri by two mercury compounds - $\mathrm{HgCl} 2$ and $\mathrm{CH} 3 \mathrm{HgCl}$ - analysis at the organism and organ levels. Wat. Air Soil Pollut. 26: 137-148 
Brouwer, M., Engel, D. W. (1982). Stoichiometry and functional consequences of $\mathrm{Hg}(\mathrm{II})$ and $\mathrm{Cd}$ (II) binding to arthropod hemocyanins. In: Vernberg, V. B., Calabrese, A., Thurberg, F. P., Vernberg, F. J (eds.) Physiological mechanisms of marine pollutant toxicity. Academic Press, New York, p. 289-310

Chen, R. W., Ganther, H. E., Hoekstra, W. G. (1973). Studies on the binding of methylmercury by thionein. Biochem. biophys. Res. Commun. 51: 383-390

Chen, R. W., Lacy, V. L., Whanger, P. D. (1975). Effect of selenium on methylmercury binding to subcellular and soluble proteins in rat tissues. Res. Comm. chem. Pathol. Pharmacol. 12: 297-308

Davies, I. M., Russel, R. (1988). The influence of dissolved selenium compounds on the accumulation of inorganic and methylated mercury compounds from solution by the mussel Mytilus edulis and the plaice Pleuronectes platessa. Sci. total Environ. 68: 197-205

Eganhouse, R. P., Young, D. R. (1978). Total and organic mercury in benthic organisms near a major submarine wastewater outfall system. Bull. environ. Contam. Toxicol. 19: $758-766$

Fang, S. C. (1977). Interaction of selenium and mercury in the rat. Chem. biol. Interactions 17: 25-40

Fowler, S.W., Heyraud, M., La Rosa, J. (1978). Factors affecting methyl and inorganic mercury dynamics in mussel and shrimp. Mar. Biol. 46: 267-276

Gardner, W. S., Kendall, D. R., Odum, R. R., Windom, H. L., Stephens, J. A. (1978). The distribution of methylmercury in a contaminated salt marsh ecosystem. Environ. Pollut. 15: $243-251$

Johnels, A. G., Westermark, T., Berg, W., Persson, P. I., Sjöstrand, B. (1967). Pike (Esox lucius L.) and some other aquatic organisms in Sweden as indicators of mercury contamination in the environment. Oikos 18: 323-333

Kiørboe, T., Møhlenberg, F., Riisgård, H. U. (1983). Mercury levels in fish, invertebrates and sediment in a recently recorded polluted area (Nissum Broad, Western Limfjord; Denmark). Mar. Pollut. Bull. 14: 21-24

Knauer, G. A., Martin, J. H. (1972). Mercury in a pelagic food chain. Limnol. Oceanogr. 17: 868-876

Koeman, J. H., Peeters, W. H. M., Koudstaal-Hol, C. H. M., Tjioe, P. S., de Goeij, J. J. M. (1973). Mercury-selenium correlations in marine mammals. Nature 245: 385-386

Koeman, J. H., van de Ven, W. M. S., de Goeij, J. J. M., Tjioe, P. S., van Haaften, J. L. (1975). Mercury and selenium in marine mammals and birds. Sci. total Environ. 3: 279-287

Lucu, C., Skreblin, M. (1981). Evidence in the interaction of mercury and selenium in the shrimp Palaemon elegans. Mar. environ. Res. 5: 265-274

Luoma, S. N. (1976). The uptake and interorgan distribution of mercury in a carnivorous crab. Bull. environ. Contam. Toxicol. 16: 719-723

Mackay, N. J., Kazakos, M. N., Williams, R. J., Leedow, M. I. (1975). Selenium and heavy metals in black marlin. Mar. Pollut. Bull. 6: 57-61

Magos, L., Webb, M. (1980). The interactions of selenium with cadmium and mercury. CRC crit. Rev, Toxicol. 8: 1-42
Mason, R. P., Fitzgerald, W. F. (1990). Alkylmercury species in the equatorial Pacific. Nature 347:457-459

Møhlenberg, F., Riisgård, H. U. (1988). Partitioning of inorganic and organic mercury in cockles Cardium edule (L.) and C. glaucum (Bruguiére) from a chronically polluted area: influence of size and age. Environ. Pollut. 55: $137-148$

Norheim, G. (1987). Levels and interactions of heavy metals in sea birds from Svalbard and the Antarctic. Environ. Pollut. 47: $83-94$

Olafson, R. W., Kearns, A., Sim, R. G. (1979). Heavy metal induction of metallothionein synthesis in the hepatopancreas of the crab Scylla serrata. Comp. Biochem. Physiol. 62B: 417-424

Parizek, J., Ostadalova, I. (1967). The protective effect of small amounts of selenite in sublimate intoxication. Experientia 23: 142-143

Patel, B., Chandy, J. P., Patel, S. (1988). Do selenium and glutathione inhibit the toxic effects of mercury in marine lamellibranchs? Sci. total Environ. 76: 147-165

Pelletier, E. (1985). Mercury-selenium interactions in aquatic organisms: a review. Mar. environ. Res. 18: 111-132

Pelletier, E. (1986). Modification de la bioaccumulation du selenium chez Mytilus edulis en présence du mercure organique et inorganique. Can. J. Fish. Aquat. Sci. 43: 203-210

Pentreath, R. J. (1976). The accumulation of mercury from food by the plaice Pleuronectes platessa L. J. exp. mar Biol. Ecol. 25: 51-65

Phillips, G. R., Gregory, R. W. (1979). Assimilation efficiency of dietary methylmercury by northern pike (Esox lucius). J. Fish. Res. Bd Can. 36: 1516-1519

Riisgård, H. U. (1984). Mercury pollution in the waters around Harboøre Tange and Limfjord, Denmark. Mar. Pollut. Bull. 15: $129-133$

Riisgård, H. U., Fammé, P. (1986). Accumulation of inorganic and organic mercury in shrimp Crangon crangon. Mar. Pollut. Bull. 17: 255-257

Riisgård, H. U., Hansen, S. (1990). Biomagnification of mercury in a marine grazing food-chain: algal cells Phaeodactylum tricornutum, mussels Mytilus edulis and flounders Platichthys flesus studied by means of a stepwise-reduction-CVAA method. Mar. Ecol. Prog. Ser. 62: 259-270

Riisgård, H. U., Kiørboe, T., Møhlenberg, F., Drabæk, I., Pheiffer Madsen, P. (1985). Accumulation, elimination and chemical speciation of mercury in the bivalves Mytilus edulis and Macoma balthica. Mar. Biol. 86: 55-62

Sørensen, M., Bjerregaard, P. (1991). Interactive accumulation of mercury and selenium in the sea star Asterias rubens. Mar. Biol. 108: 269-276

Wong, V. W. T., Rainbow, P. S. (1986a). Two metallothioneins in the shore crab Carcinus maenas. Comp. Biochem. Physiol. 83A: 149-156

Wong, V. W. T., Rainbow, P. S. (1986b). Apparent and real variability in the presence and metal contents of metallothioneins in the crab Carcinus maenas including the effects of isolation procedure and metal induction. Comp. Biochem. Physiol. 83A: 157-177

Manuscript first received: May 25, 1992

Revised version accepted: June 26,1993

This article was submitted to the editor 